\title{
Synthesis and biological evaluation of some novel pyrazolopyrimidines incorporating a benzothiazole ring system
}

\author{
MOHAMMED AFZAL AZAM* \\ LOGANATHAN DHARANYA \\ CHARU CHANDRAKANT MEHTA \\ SUMIT SACHDEVA \\ Department of Pharmaceutical \\ Chemistry, J. S. S. College of Pharmacy \\ Ootacamund, India
}

Accepted September 28, 2012

\begin{abstract}
In the present study, a series of benzothiazol derivatives 3a-1 containing pyrazolo[3,4-d]pyrimidine moiety at the second position were synthesized and characterized by analytical and spectral data. The compounds were tested for their in vitro antimicrobial activity. Compounds 1-(1,3-benzothiazol-2yl)-3-methyl-4-phenyl- $1 H$-pyrazolo[3,4-d]pyrimidine (3a), 1(1,3-benzothiazol-2-yl)-4-(4-chlorophenyl)-3-methyl-1H-pyrazolo[3,4-d]pyrimidine (3d) and 1-(1,3-benzothiazol-2-yl)3-methyl-4-substituted phenyl-1H-pyrazolo[3,4- $d$ ]pyrimidines (3h-j) showed significant inhibitory activity against $P$. aeruginosa whereas compounds 1-(1,3-benzothiazol-2-yl)-4(2-chlorophenyl)-3-methyl-1H-pyrazolo[3,4- $d$ ]pyrimidine (3b), 2-[1-(1,3-benzothiazol-2-yl)-3-methyl-1H-pyrazolo[3,4-d]pyrimidin-4-yl]phenol (3e), 1-(1,3-benzothiazol-2-yl)-4-(3,4-dimethoxyphenyl)-3-methyl- $1 H$-pyrazolo[3,4-d]pyrimidine $(3 \mathrm{~h})$, 4-[1-(1,3-benzothiazol-2-yl)-3-methyl-1H-pyrazolo[3,4-d]pyri midin-4-yl]-N,N-dimethylaniline (3j) and 1-(1,3-benzothiazol-2-yl)-3-methyl-4-[2-phenylvinyl]-1H-pyrazolo[3,4-d]pyrimidine (3k) were found to be active against $C$. albicans. Some of these synthesized compounds were evaluated for their in vivo acute toxicity, analgesic, anti-inflammatory, and ulcerogenic actions. The tested compound 4-[1-(1,3-benzothiazol-2-yl)-3-methyl-1H-pyrazolo[3,4-d]pyrimidin-4-yl]-N, $\mathrm{N}$-dimethylaniline (3j) exhibited maximum analgesic and anti-inflammatory activities. Compounds 1-(1,3-benzothiazol-2-yl)-3-methyl-4-(3-nitrophenyl)-1H-pyrazolo[3,4-d]pyrimidine $(3 \mathbf{i})$ and $3 \mathbf{j}$ showed a significant gastrointestinal protection compared to the standard drug diclofenac sodium.
\end{abstract}

Keywords: benzothiazoles, pyrazolo[3,4- $d]$ pyrimidine, antimicrobial activity, anti-inflammatory activity

A major mechanism of action of nonsteroidal anti-inflammatory drugs (NSAIDs) is the lowering of prostaglandin (PG) production through inhibition of the cyclooxygenase (COX) enzyme, which catalyzes the conversion of arachidonic acid into PG (1). Since PG

\footnotetext{
* Correspondence; e-mail: afzal9azam@hotmail.com
} 
has a dual function, mediation of inflammation (2) and cytoprotection (3) in the stomach and intestine, long-term usage of NSAIDs to relieve the symptoms of inflammation and pain always results in gastrointestinal (GI) disorders and renal toxicity (4). It is known that bacterial infections often produce pain and inflammation. In normal practice, chemotherapeutic, analgesic, and anti-inflammatory drugs are prescribed simultaneously, which increases the risk of developing NSAIDs-related complications, especially in the elderly, patients with a prior history of peptic ulcer disease and patients with impaired kidney functions. Hence, there is a pressing need for drugs having both antimicrobial and analgesic/anti-inflammatory activities with minimum adverse effects.

Pyrazolo[3,4- $d]$ pyrimidine and related fused heterocycles are of interest as potential bioactive molecules and have received a great deal of attention due to their useful antibacterial (5), antifungal (6) and anti-inflammatory (7) properties. In addition, many benzothiazole derivatives exhibit a wide variety of biological activities [antimicrobial $(8,9)$ and anti-inflammatory $(10,11)]$. Based on the above observations and with the aim of developing new dual acting antimicrobial/anti-inflammatory agents with minimum ulcerogenic effects, it appeared of interest to link the benzothiazole nucleus at the second position to some pyrazolo[3,4-d]pyrimidine moiety. This is an attempt to investigate the influence of such hybridization and structure variation on the anticipated biological activities, hoping to add some synergistic biological significance to the target molecules. In the present investigation, we aimed to synthesize novel benzothiazole incorporated pyrazolo[3,4- $d]$ pyrimidine derivatives and evaluate their antimicrobial, analgesic, anti-inflammatory and ulcerogenic activities.

\section{EXPERIMENTAL}

Requisite chemicals were of reagent grade and were purified when necessary. Melting points were determined in open glass capillaries and are uncorrected. The reaction progress was routinely monitored by thin layer chromatography (TLC) on silica gel plates (Merck $60 \mathrm{~F}_{254}$, Germany). The IR spectra were recorded on a Shimadzu $8400 \mathrm{~S}$ FT-IR spectrometer (Japan) in $\mathrm{KBr}$ pellets and band positions are given in reciprocal centimeters $\left(\mathrm{cm}^{-1}\right)$. The ${ }^{1} \mathrm{H}$ NMR and ${ }^{13} \mathrm{C}$ NMR spectra were recorded using a Bruker AV-III 400 spectrometer (Germany) with dimethyl sulfoxide (DMSO)- $d_{6}$ as solvent. Chemical shifts were reported in ppm using the solvent as internal standard. Mass spectra were measured on a Shimadzu LC-MS 2010A mass spectrometer (Japan) equipped with a manual injector, a photodiode array detector, an electrospray ionization source and a single-quadrupole mass analyzer in both positive and negative ion modes. Elemental analyses were carried out on a Flash EA 1112 series instrument (Thermo Finnigan, Italy).

2-Hydrazino-1,3-benzothiazole (1) and 1-(1,3-benzothiazol-2-yl)-3-methyl-1,4-dihydro- $5 \mathrm{H}$-pyrazol-5-one (2) were prepared by the procedure described in the literature (12, 13).

Synthesis of 1-(1,3-benzothiazol-2-yl)-3-methyl-4-substituted phenyl-1H-pyrazolo[3,4-d Jpyrimidine derivatives $(3 a-l)$. General procedure

A mixture of 1-(1,3-benzothiazol-2-yl)-3-methyl-1,4-dihydro-5 $\mathrm{H}$-pyrazol-5-one (2) $(10 \mathrm{mmol}, 2.31 \mathrm{~g})$, urea $(10 \mathrm{mmol}, 0.60 \mathrm{~g})$ and appropriate araldehyde (10 mmol, for 
benzaldehyde $1.06 \mathrm{~g}$, 2,3 or 4-chlorobenzaldehyde $1.40 \mathrm{~g}$, 2 or 4-hydroxybenzaldehyde $1.22 \mathrm{~g}$, 4-methoxybenzaldehyde $1.36 \mathrm{~g}$, 3,4-dimethoxybenzaldehyde $1.66 \mathrm{~g}$, 3-nitrobenzaldehyde $1.51 \mathrm{~g}$, 4-dimethylaminobenzaldehyde $1.49 \mathrm{~g}$, cinnamaldehyde $1.32 \mathrm{~g}$, 2-furfuraldehyde $0.96 \mathrm{~g})$ in absolute ethanol $(30 \mathrm{~mL})$ was heated under reflux on a water bath for 7-8 h. The mixture was concentrated in vacuo and cooled to room temperature. The separated solid was filtered, washed several times with water, dried and recrystallized from appropriate solvent to give the title compounds $3 \mathbf{a}-\mathbf{1}$.

Physicochemical and spectral data for the synthesized compounds are given in Tables I and II. Synthetic route is represented in Scheme 1.

Solvent for crystallization: for $3 \mathbf{a}, \mathbf{3 c}-\mathbf{f}, \mathbf{3 h}, \mathbf{3} \mathbf{i}$ acetone, for $\mathbf{3 b}, \mathbf{3} \mathbf{j}$ chloroform and methanol 1:1, for $\mathbf{3 g}$, 31 methanol, for $\mathbf{3 k}$ chloroform and petroleum ether 1:1

Table I. Physicochemical properties of the synthesized compounds $3 a-1$

\begin{tabular}{|c|c|c|c|c|c|c|c|}
\hline \multirow{2}{*}{ Compd. } & \multirow{2}{*}{$\mathrm{Ar}$} & \multirow{2}{*}{$\begin{array}{c}\text { Formula } \\
\left(M_{\mathrm{r}}\right)\end{array}$} & \multirow{2}{*}{$\begin{array}{c}\text { Yield } \\
(\%)\end{array}$} & \multirow{2}{*}{$\begin{array}{l}\text { M.p. } \\
\left({ }^{\circ} \mathrm{C}\right)\end{array}$} & \multicolumn{3}{|c|}{ Analysis (calcd./found, \%) } \\
\hline & & & & & $\mathrm{C}$ & $\mathrm{H}$ & $\mathrm{N}$ \\
\hline $3 a$ & $\mathrm{C}_{6} \mathrm{H}_{5}$ & $\begin{array}{c}\mathrm{C}_{19} \mathrm{H}_{13} \mathrm{~N}_{5} \mathrm{~S} \\
(343.40)\end{array}$ & 66 & 165 & $66.47 / 66.50$ & $3.79 / 3.82$ & $20.40 / 20.46$ \\
\hline $3 b$ & $2-\mathrm{Cl}-\mathrm{C}_{6} \mathrm{H}_{4}$ & $\begin{array}{c}\mathrm{C}_{19} \mathrm{H}_{12} \mathrm{ClN}_{5} \mathrm{~S} \\
(377.85)\end{array}$ & 67 & 228 & $60.31 / 60.29$ & $3.17 / 3.20$ & $18.51 / 18.56$ \\
\hline $3 c$ & $3-\mathrm{Cl}-\mathrm{C}_{6} \mathrm{H}_{4}$ & $\begin{array}{c}\mathrm{C}_{19} \mathrm{H}_{12} \mathrm{ClN}_{5} \mathrm{~S} \\
(377.85)\end{array}$ & 61 & 203 & $60.31 / 60.36$ & $3.17 / 3.13$ & $18.51 / 18.49$ \\
\hline $3 d$ & $4-\mathrm{Cl}-\mathrm{C}_{6} \mathrm{H}_{4}$ & $\begin{array}{c}\mathrm{C}_{19} \mathrm{H}_{12} \mathrm{ClN}_{5} \mathrm{~S} \\
(377.85)\end{array}$ & 70 & 185 & $60.31 / 60.28$ & $3.17 / 3.13$ & $18.51 / 18.56$ \\
\hline $3 e$ & $2-\mathrm{HO}-\mathrm{C}_{6} \mathrm{H}_{4}$ & $\begin{array}{c}\mathrm{C}_{19} \mathrm{H}_{13} \mathrm{~N}_{5} \mathrm{OS} \\
(359.40)\end{array}$ & 66 & 225 & $63.50 / 63.46$ & $3.62 / 3.68$ & $19.49 / 19.54$ \\
\hline $3 f$ & $4-\mathrm{HO}-\mathrm{C}_{6} \mathrm{H}_{4}$ & $\begin{array}{c}\mathrm{C}_{19} \mathrm{H}_{13} \mathrm{~N}_{5} \mathrm{OS} \\
(359.40)\end{array}$ & 61 & 280 & $63.50 / 63.53$ & $3.62 / 3.58$ & $19.49 / 19.45$ \\
\hline $3 g$ & $4-\mathrm{CH}_{3} \mathrm{O}-\mathrm{C}_{6} \mathrm{H}_{4}$ & $\begin{array}{c}\mathrm{C}_{20} \mathrm{H}_{15} \mathrm{~N}_{5} \mathrm{OS} \\
(373.43)\end{array}$ & 69 & 165 & $62.53 / 62.49$ & $4.21 / 4.19$ & $18.77 / 18.81$ \\
\hline $3 h$ & 3,4-di- $\mathrm{CH}_{3} \mathrm{O}-\mathrm{C}_{6} \mathrm{H}_{3}$ & $\begin{array}{c}\mathrm{C}_{21} \mathrm{H}_{17} \mathrm{~N}_{5} \mathrm{O}_{2} \mathrm{~S} \\
(403.45)\end{array}$ & 62 & 198 & $62.53 / 62.49$ & $4.21 / 4.19$ & $17.36 / 17.31$ \\
\hline $3 \mathbf{i}$ & $3-\mathrm{NO}_{2}-\mathrm{C}_{6} \mathrm{H}_{4}$ & $\begin{array}{c}\mathrm{C}_{19} \mathrm{H}_{12} \mathrm{~N}_{6} \mathrm{O}_{2} \mathrm{~S} \\
(388.40)\end{array}$ & 72 & 171 & $58.76 / 58.80$ & $3.09 / 3.13$ & $21.64 / 21.69$ \\
\hline $3 \mathbf{j}$ & $4-\mathrm{N}\left(\mathrm{CH}_{3}\right)_{2}-\mathrm{C}_{6} \mathrm{H}_{4}$ & $\begin{array}{c}\mathrm{C}_{21} \mathrm{H}_{18} \mathrm{~N}_{6} \mathrm{~S} \\
(386.47)\end{array}$ & 67 & 240 & $65.28 / 65.32$ & $4.66 / 4.69$ & $21.76 / 21.81$ \\
\hline $3 k$ & $\mathrm{C}_{6} \mathrm{H}_{5}-\mathrm{CH}=\mathrm{CH}$ & $\begin{array}{c}\mathrm{C}_{21} \mathrm{H}_{15} \mathrm{~N}_{5} \mathrm{~S} \\
(369.44)\end{array}$ & 61 & 195 & $68.29 / 68.33$ & $4.06 / 4.11$ & $18.97 / 18.92$ \\
\hline 31 & 2-furyl & $\begin{array}{c}\mathrm{C}_{17} \mathrm{H}_{11} \mathrm{~N}_{5} \mathrm{OS} \\
(333.36)\end{array}$ & 62 & 180 & $61.26 / 61.31$ & $3.30 / 3.36$ & $21.02 / 21.08$ \\
\hline
\end{tabular}




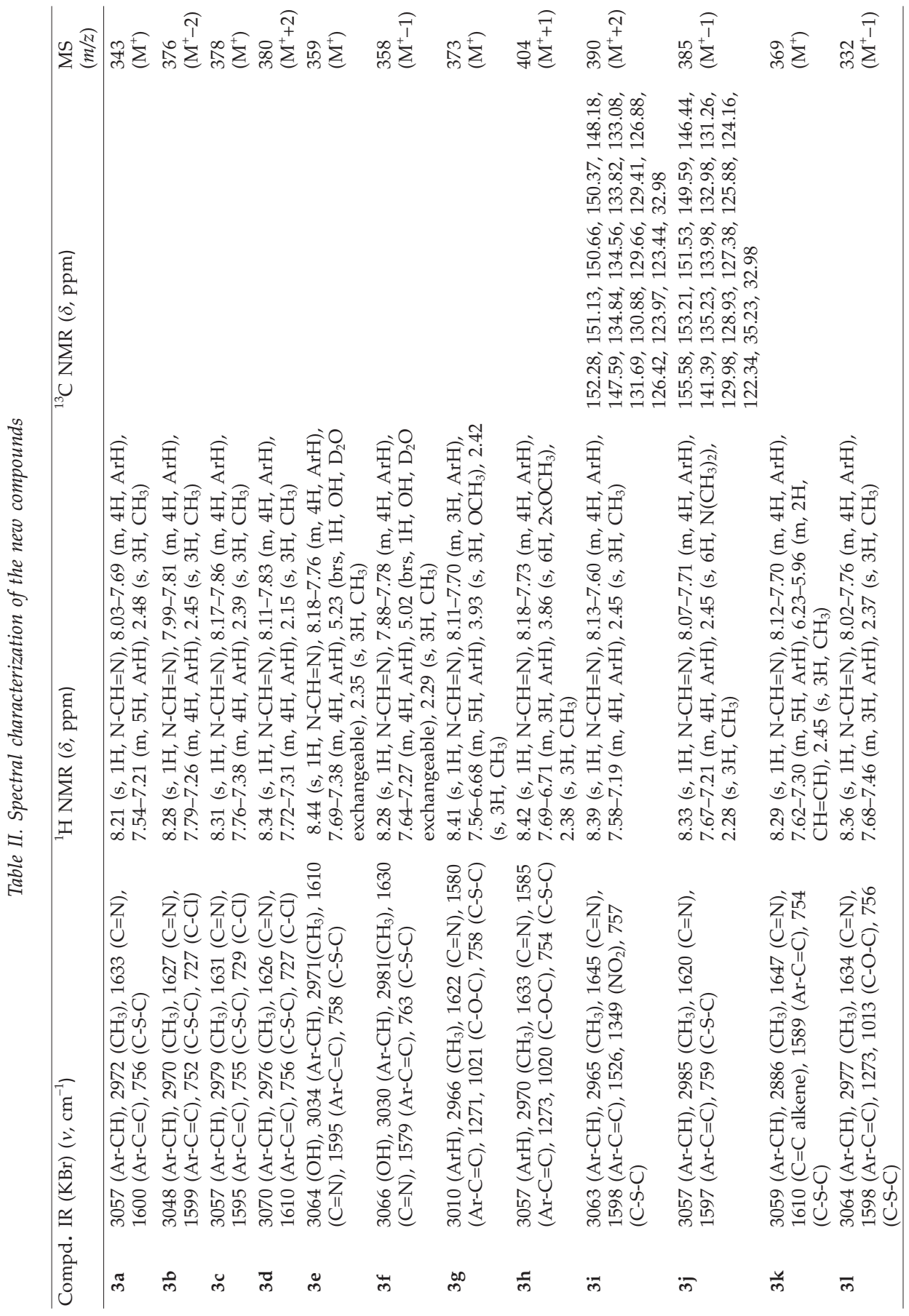




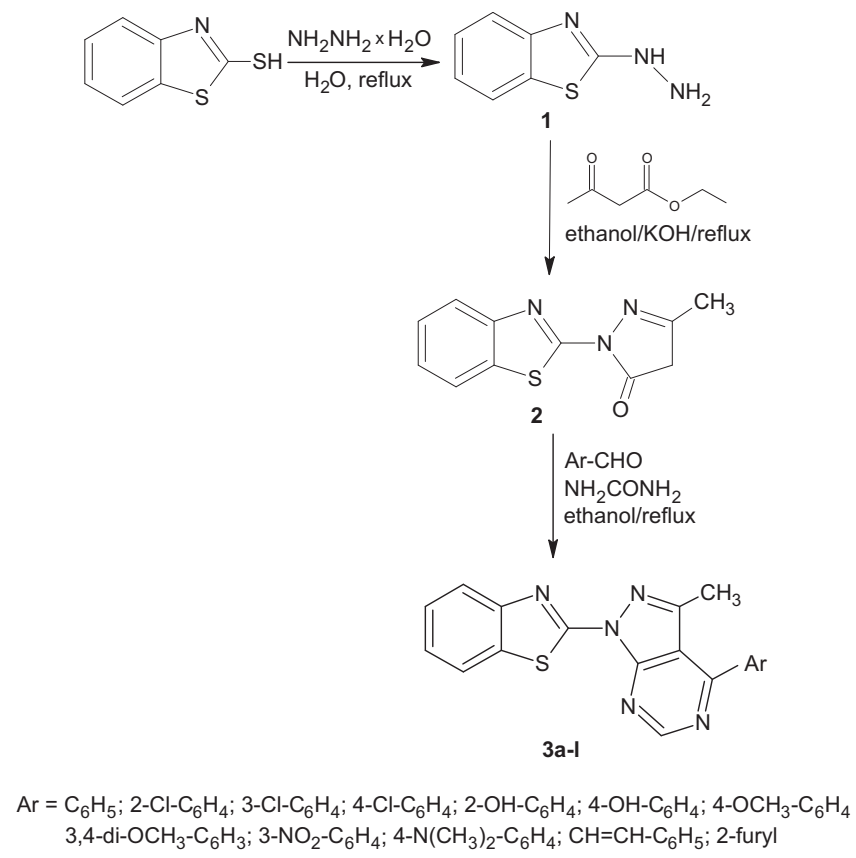

Scheme 1

\section{Biological study}

Antimicrobial activity. - Standard strains were procured from the National Collection of Industrial Microorganism, National Chemical Laboratory, India. Synthesized compounds 3a-1 were tested [50 and $100 \mu \mathrm{g} \mathrm{mL}^{-1}$ in sterile dimethyl sulfoxide (DMSO)] for their in vitro antimicrobial activity by the cup plate diffusion method (14). The antibacterial activity was evaluated on nutrient agar (Hi-media) plates $\left(37^{\circ} \mathrm{C}, 24 \mathrm{~h}\right.$ ) against Gram-positive bacteria Staphylococcus aureus NCIM 2079, Bacillus megaterium NCIM 2187, Gram-negative bacteria Escherichia coli NCIM 2567 and Pseudomonas aeruginosa NCIM 2036. Test compounds were also evaluated for their antifungal potential on Sabouraud dextrose agar (Hi-media) plates $\left(26^{\circ} \mathrm{C}, 48-72 \mathrm{~h}\right)$ against Candida albicans NCIM 3100. Ciprofloxacin and ketoconazole were used as control drugs as 10 and $20 \mu \mathrm{g} \mathrm{mL}-1$ solutions, respectively, in sterile dimethyl sulfoxide. Average diameter of inhibition zone (three independent evaluations) of bacterial or fungal growth around the disk in mm (Table III) were recorded.

Animals. - Experimental animals were procured from the M/S Venkatesh Enterprises, India. The animals were fed a standard rodent diet (Hindustan Liver Ltd., India) with water ad libitum and were housed in rooms maintained at $23 \pm 2{ }^{\circ} \mathrm{C}$ with a $12 \mathrm{~h}$ light/dark cycle and relative humidity 45-50\%. The Animal Ethics Committee of the J. S. S. College of Pharmacy, Ootacamund, India, approved all experimental protocols, in accordance with the Indian Government Legislation on Animal Care. Synthesized com- 
M. A. Azam et al.: Synthesis and biological evaluation of some novel pyrazolopyrimidines incorporating a benzothiazole ring system, Acta Pharm. 63 (2013) 19-30.

Table III. Antimicrobial activity of synthesized compounds $3 a-l^{\text {a }}$

\begin{tabular}{|c|c|c|c|c|c|}
\hline \multirow[b]{2}{*}{ Compd. } & \multicolumn{5}{|c|}{ Zone of inhibition (mm) } \\
\hline & $\begin{array}{c}\text { Staphylococcus } \\
\text { aureus }\end{array}$ & $\begin{array}{c}\text { Bacillus } \\
\text { megaterium }\end{array}$ & $\begin{array}{c}\text { Escherichia } \\
\text { coli }\end{array}$ & $\begin{array}{c}\text { Pseudomonas } \\
\text { aeruginosa }\end{array}$ & $\begin{array}{l}\text { Candida } \\
\text { albicans }\end{array}$ \\
\hline $3 a$ & 13 & - & 19 & 23 & 16 \\
\hline $3 b$ & 13 & - & 17 & 19 & 24 \\
\hline $3 c$ & - & - & 18 & 19 & 22 \\
\hline $3 d$ & 12 & 12 & 21 & 27 & 18 \\
\hline $3 e$ & 12 & - & 20 & 19 & 24 \\
\hline $3 f$ & 13 & 12 & 19 & 19 & 23 \\
\hline $3 g$ & 11 & - & 21 & 18 & 22 \\
\hline $3 h$ & 13 & - & 19 & 23 & 26 \\
\hline $3 \mathbf{i}$ & 12 & 13 & 21 & 24 & 21 \\
\hline $3 \mathbf{j}$ & 12 & 12 & 22 & 22 & 26 \\
\hline $3 \mathbf{k}$ & 13 & - & 19 & 18 & 24 \\
\hline 31 & 12 & 12 & 21 & 23 & 13 \\
\hline Ciprofloxacin & 30 & 35 & 41 & 50 & - \\
\hline Ketoconazole & - & - & - & - & 32 \\
\hline DMSO & - & - & - & - & - \\
\hline
\end{tabular}

- no activity.

a Average of three independent determinations. Concentration tested: compounds 3a-1 $100 \mu \mathrm{g} \mathrm{mL} \mathrm{L}^{-1}$, ciprofloxacin $10 \mu \mathrm{g} \mathrm{mL}-1$, ketoconazole $20 \mu \mathrm{g} \mathrm{mL}$.

pounds 3a-1 were evaluated for their acute toxicity, analgesic and anti-inflammatory activities. Data were statistically analyzed by one-way analysis of variance (ANOVA) followed by Student's $t$-test to assess the statistical significance.

Acute toxicity. - Acute oral toxicity was checked for compounds 3a-1 following the Organization of Economic Cooperation and Development (OECD-423) guidelines (15) (acute toxic class method). Swiss albino mice $(n=3)$ of either sex (38-45 g), selected by random sampling, were used for the study. The animals were fasted for $3-4 \mathrm{~h}$ with water ad libitum, after which the test compounds were administered orally as a suspension in $1 \%$ carboxymethylcellulose (CMC) $\left(\mathrm{m} / \mathrm{V}\right.$, in water) at doses of 50, 100, 250, 500 and $1000 \mathrm{mg} \mathrm{kg}^{-1}$ body mass. The mice were observed for three days.

Analgesic activity by acetic acid induced writhing method. - Analgesic activity of the synthesized compounds was evaluated by the acetic acid induced writhing method (16) using Swiss albino mice $(n=6)$ of either sex (35-48 g). The test compounds and diclofenac sodium were suspended in $1.0 \% \mathrm{CMC}$ and administered orally. One hour after administration of the test compounds, $0.10 \mathrm{~mL}$ acetic acid solution $(1.0 \%, \mathrm{~m} / \mathrm{V}$, in sterile saline) was injected intraperitoneally and stretching movements comprising of arching of the back, body elongation and extension of hind limbs were counted for $15 \mathrm{~min}$. The analgesic activity was expressed in terms of percentage inhibition (Table IV). 
M. A. Azam et al.: Synthesis and biological evaluation of some novel pyrazolopyrimidines incorporating a benzothiazole ring system, Acta Pharm. 63 (2013) 19-30.

Table IV. Analgesic activity of some selected compounds in mice by the acetic induced writhing method

\begin{tabular}{cccccccc}
\hline Compd. & $3 \mathbf{a}$ & $\mathbf{3 d}$ & $3 \mathbf{h}$ & $3 \mathbf{i}$ & $3 \mathbf{j}$ & $3 \mathbf{l}$ & $\begin{array}{c}\text { Diclofenac } \\
\text { sodium }\end{array}$ \\
\hline $\begin{array}{c}\text { Inhibition } \\
(\%)^{\mathrm{a}}\end{array}$ & $41.7 \pm 1.3^{\mathrm{c}}$ & $37.3 \pm 0.8^{\mathrm{c}}$ & $55.2 \pm 1.2^{\mathrm{c}}$ & $56.3 \pm 1.2^{\mathrm{d}}$ & $59.6 \pm 0.9^{\mathrm{c}}$ & $36.6 \pm 0.6^{\mathrm{b}}$ & $62.6 \pm 1.3^{\mathrm{c}}$ \\
\hline
\end{tabular}

Test compounds and diclofenac sodium were tested at 0.30 and $0.06 \mathrm{mmol} \mathrm{kg}{ }^{-1}$ body mass, respectively.

a Mean \pm SEM, $n=6$.

Significance levels compared to the control: ${ }^{\mathrm{b}} p<0.05,{ }^{\mathrm{c}} p<0.01$ and ${ }^{\mathrm{d}} p<0.001$.

Analgesic activity by Eddy's hot plate method. - Analgesic activity of the synthesized compounds was also evaluated by Eddy's hot plate method (17) using Swiss albino mice $(n=6)$ of either sex $(44-52 \mathrm{~g})$. The test compounds and paracetamol were administered orally suspended in $1.0 \%$ CMC. One hour after administration of the test compounds, animals were individually placed on hot plate maintained at $55 \pm 0.5{ }^{\circ} \mathrm{C}$. The response time was noted as the time at which animals reacted to the pain stimulus either by paw licking or jump response, whichever appeared first. The reaction time in control and treated animals was recorded at $0.5,1,2$ and $3 \mathrm{~h}$ after the treatment. The cut off time for the reaction was 15 seconds. Results are presented in Table V.

Anti-inflammatory activity. - The acute anti-inflammatory activity of the synthesized compounds was determined following the carrageenean induced paw oedema method (18) in Wistar albino rats $(n=6)$ of either sex $(155-180 \mathrm{~g})$. The animals were fasted for $24 \mathrm{~h}$ before the experiment with free access to water. The test compounds and diclofenac sodium were administered orally as a suspension in $1.0 \%$ CMC. Control rats received appropriate volumes of $1.0 \%$ CMC solution orally. Thirty minutes after administration of the test compounds, $0.1 \mathrm{~mL}$ carrageenean solution $(1.0 \%, \mathrm{~m} / \mathrm{V}$, in sterile saline) was injected into the sub-plantar tissue of the right hind paw of each rat. Paw volume was measured at time intervals of $0.5,1,2$ and $3 \mathrm{~h}$ after carrageenean injection by means of a plethysmometer (UGO Basile 7140, India). The anti-inflammatory activity results are summarized in Table VI.

Table V. Analgesic activity of some selected compounds in mice by Eddy's hot plate method

\begin{tabular}{ccccc}
\hline \multirow{2}{*}{ Compd. } & \multicolumn{4}{c}{ Analgesic activity $^{\mathrm{a}}$} \\
\cline { 2 - 5 } & $0.5 \mathrm{~h}$ & $1 \mathrm{~h}$ & $2 \mathrm{~h}$ & $3 \mathrm{~h}$ \\
\hline $3 \mathbf{3 a}$ & $32.1 \pm 0.9^{\mathrm{c}}$ & $60.3 \pm 1.2^{\mathrm{d}}$ & $39.7 \pm 0.8^{\mathrm{c}}$ & $24.6 \pm 1.0^{\mathrm{c}}$ \\
3d & $30.8 \pm 0.9^{\mathrm{c}}$ & $64.4 \pm 1.0^{\mathrm{c}}$ & $51.5 \pm 1.2^{\mathrm{c}}$ & $26.1 \pm 1.2^{\mathrm{d}}$ \\
3h & $50.0 \pm 1.1^{\mathrm{c}}$ & $73.2 \pm 1.1^{\mathrm{c}}$ & $75.0 \pm 1.5^{\mathrm{b}}$ & $61.4 \pm 1.0^{\mathrm{c}}$ \\
$3 \mathbf{3 i}$ & $58.4 \pm 1.3^{\mathrm{c}}$ & $43.4 \pm 0.8^{\mathrm{c}}$ & $35.1 \pm 1.1^{\mathrm{d}}$ & $27.0 \pm 1.1^{\mathrm{d}}$ \\
$3 \mathbf{j}$ & $40.4 \pm 1.3^{\mathrm{c}}$ & $54.9 \pm 1.2^{\mathrm{d}}$ & $51.7 \pm 1.1^{\mathrm{c}}$ & $39.6 \pm 0.9^{\mathrm{b}}$ \\
$3 \mathbf{P a r a c e t a m o l}$ & $49.8 \pm 1.2^{\mathrm{d}}$ & $51.7 \pm 1.2^{\mathrm{b}}$ & $67.5 \pm 1.1^{\mathrm{c}}$ & $61.6 \pm 1.3^{\mathrm{c}}$ \\
\hline
\end{tabular}

Test compounds and paracetamol were tested at 0.30 and $0.66 \mathrm{mmol} \mathrm{kg}^{-1}$ body mass, respectively.

a Mean \pm SEM, $n=6$.

Significance levels compared to the respective control: ${ }^{\mathrm{b}} p<0.05,{ }^{\mathrm{c}} p<0.01$ and ${ }^{\mathrm{d}} p<0.001$. 
M. A. Azam et al.: Synthesis and biological evaluation of some novel pyrazolopyrimidines incorporating a benzothiazole ring system, Acta Pharm. 63 (2013) 19-30.

Table VI. Anti-inflammatory activity of some selected compounds by the carrageenean induced rat paw oedema method

\begin{tabular}{ccccc}
\hline \multirow{2}{*}{ Compd. } & \multicolumn{4}{c}{ Protection $^{\mathrm{a}}$} \\
\cline { 2 - 5 } & $30 \mathrm{~min}$ & $1 \mathrm{~h}$ & $2 \mathrm{~h}$ & $3 \mathrm{~h}$ \\
\hline 3a & $17.0 \pm 0.9^{\mathrm{b}}$ & $36.7 \pm 0.7^{\mathrm{b}}$ & $38.4 \pm 0.8^{\mathrm{c}}$ & $27.2^{\mathrm{a}} \pm 1.1^{\mathrm{c}}$ \\
3d & $12.5 \pm 1.1^{\mathrm{d}}$ & $14.8 \pm 1.2^{\mathrm{d}}$ & $21.7 \pm 1.2^{\mathrm{d}}$ & $30.0 \pm 1.1^{\mathrm{b}}$ \\
3h & $13.3 \pm 1.3^{\mathrm{c}}$ & $20.7 \pm 0.8^{\mathrm{d}}$ & $41.6 \pm 1.0^{\mathrm{c}}$ & $35.9 \pm 0.7^{\mathrm{c}}$ \\
$3 \mathbf{i}$ & $44.6 \pm 1.2^{\mathrm{c}}$ & $29.1 \pm 1.1^{\mathrm{c}}$ & $28.4 \pm 1.3^{\mathrm{c}}$ & $23.9 \pm 1.2^{\mathrm{c}}$ \\
3j & $56.8 \pm 1.0^{\mathrm{d}}$ & $67.7 \pm 1.2^{\mathrm{b}}$ & $74.7 \pm 1.0^{\mathrm{d}}$ & $47.6 \pm 0.7^{\mathrm{d}}$ \\
31 & $19.5 \pm 1.1^{\mathrm{b}}$ & $29.5 \pm 1.4^{\mathrm{b}}$ & $17.6 \pm 1.3^{\mathrm{c}}$ & $17.5 \pm 1.1^{\mathrm{b}}$ \\
Diclofenac sodium & $29.9 \pm 1.2^{\mathrm{d}}$ & $49.3 \pm 0.9^{\mathrm{b}}$ & $61.1 \pm 1.2^{\mathrm{c}}$ & $72.0 \pm 0.9^{\mathrm{d}}$ \\
\hline
\end{tabular}

Test compounds and diclofenac sodium were tested at 0.30 and $0.06 \mathrm{mmol} \mathrm{kg}^{-1}$ body mass, respectively.

a Mean \pm SEM, $n=6$.

Significance levels compared to the respective control: ${ }^{\mathrm{b}} p<0.05,{ }^{\mathrm{c}} p<0.01$ and ${ }^{\mathrm{d}} p<0.001$.

Table VII. Ulcerogenic activity of some selected compounds

\begin{tabular}{cccccc}
\hline Compd. & $1 \% \mathrm{CMC}$ & $3 \mathbf{h}$ & $3 \mathbf{i}$ & $3 \mathbf{j}$ & $\begin{array}{c}\text { Diclofenac } \\
\text { sodium }\end{array}$ \\
\hline $\begin{array}{c}\text { Severity } \\
\text { index }^{\mathrm{a}}\end{array}$ & $1.1 \pm 0.8^{\mathrm{d}}$ & $3.7 \pm 0.7^{\mathrm{b}}$ & $3.5 \pm 1.2^{\mathrm{c}}$ & $3.0 \pm 0.9^{\mathrm{c}}$ & $6.1 \pm 1.1^{\mathrm{c}}$ \\
\hline
\end{tabular}

Test compounds and diclofenac sodium were tested at 0.60 and $0.12 \mathrm{mmol} \mathrm{kg}{ }^{-1}$ body mass, respectively.

a Mean \pm SEM, $n=6$.

Significance levels compared to the control: ${ }^{\mathrm{b}} p<0.05,{ }^{\mathrm{c}} p<0.01$ and ${ }^{\mathrm{d}} p<0.001$.

Ulcerogenic effects. - Test compounds $\mathbf{3 e}, \mathbf{3 h}$ and $\mathbf{3} \mathbf{j}$ were evaluated for their acute ulcerogenic effects according to the method of Cioli et al. (19) using Wistar albino rats $(n=6)$ of either sex (175-190 g). The test compounds and diclofenac sodium were administered orally as a suspension in $1 \% \mathrm{CMC}$ solution. Control group received appropriate volumes of CMC solution orally. Food, but not water, was removed $24 \mathrm{~h}$ before administration of the test compounds. After compound treatment, the rats were fed a standard diet for $17 \mathrm{~h}$ and then sacrificed. Their stomachs were removed, cut out along the greater curvature, washed with distilled water and then gently cleaned by dipping in normal saline. Mucosal damage was examined by means of a magnifying glass. For each stomach, the mucosal damage was assessed according to the following scoring system: 0.5 redness; 1.0 spot ulcers; 1.5 hemorrhagic streaks; 2.0 ulcers $>3$ but $\leq 5 ; 3.0$ ulcers $>5$ (20). The mean score of each treated group minus the mean score of the control group was regarded as the severity index of gastric mucosal damage. Results are presented in Table VII. 
M. A. Azam et al.: Synthesis and biological evaluation of some novel pyrazolopyrimidines incorporating a benzothiazole ring system, Acta Pharm. 63 (2013) 19-30.

\section{RESULTS AND DISCUSSION}

The synthetic route for the preparation of title compounds 3a-1 is outlined in Scheme 1. The intermediate 2-hydrazino-1,3-benzothiazole (1) was prepared (12) by refluxing 2-mercaptobenzothiazole with hydrazine hydrate in water. 1-(1,3-Benzothiazol-2-yl)-3methyl-1,4-dihydro-5H-pyrazol-5-one (2) was prepared (13) by the treatment of compound (1) with ethyl acetoacetate in boiling ethanolic potassium hydroxide. Further condensation of compound (2) with urea and araldehydes in refluxing absolute alcohol furnished the corresponding title compounds 1-(1,3-benzothiazol-2-yl)-3-methyl-4-substituted phenyl-1H-pyrazolo[3,4- $d$ ] pyrimidine (3a-1) in 61-72\% yield. Structures of the newly synthesized compounds were confirmed by analytical and spectral data.

The infrared spectra of compounds (3a-1) revealed absorption bands within 2986$2965 \mathrm{~cm}^{-1}$ for $\mathrm{CH}_{3}, 1647-1610 \mathrm{~cm}^{-1}$ for $\mathrm{C}=\mathrm{N}$ and $763-752 \mathrm{~cm}^{-1}$ for C-S-C stretch. Formation of pyrazolopyrimidine ring in $3 \mathbf{i}$ was supported by its ${ }^{1} \mathrm{H}$ NMR spectrum (21), which showed a singlet signal at $\delta 8.19 \mathrm{ppm}$ due to the $\mathrm{CH}=\mathrm{N}$ fragment of the pyrazolopyrimidine ring. Two multiplet signals that appeared at $\delta 8.13-7.60$ and 7.58-7.19 ppm were assigned to four aromatic protons each. Furthermore, the signal for the $\mathrm{CH}_{3}$ fragment was ascribed to a singlet at $\delta 2.45 \mathrm{ppm}$. Its mass spectrum showed an $\mathrm{M}+2$ peak at $\mathrm{m} / \mathrm{z} 390$, which is in conformity with the molecular formula $\mathrm{C}_{19} \mathrm{H}_{12} \mathrm{~N}_{6} \mathrm{O}_{2} \mathrm{~S}$. It exhibited a base peak at $m / z 232$ due to the $\mathrm{C}_{11} \mathrm{H}_{10} \mathrm{~N}_{4} \mathrm{~S}^{+}$fragment, which is consistent with the structure of this compound $3 \mathbf{i}$. In the ${ }^{13} \mathrm{C}$ NMR spectrum of compound $3 \mathbf{i}$, azomethine carbon of the benzothiazole ring resonated as a singlet signal at $\delta 152.28 \mathrm{ppm}$, whereas two signals observed at $\delta 151.13$ and $150.66 \mathrm{ppm}$ were assigned to azomethine carbons of the pyrimidine ring. The $\mathrm{C}=\mathrm{N}$ fragment of the pyrazole ring exhibited a signal at $\delta 150.37 \mathrm{ppm}$. The appearance of signals between 148.18-123.44 ppm supported the presence of fourteen $\mathrm{sp} 2$ carbon atoms. A signal at 32.98 ppm was assigned to the $\mathrm{CH}_{3}$ fragment.

In vitro antimicrobial activity of synthesized compounds by the cup plate method (14) was first tested at $50 \mu \mathrm{g} \mathrm{mL}^{-1}$ concentration, but all compounds failed to produce the antimicrobial effect against the tested microorganisms. However, at $100 \mu \mathrm{g} \mathrm{mL}^{-1}$, tested compounds $\mathbf{3 a}, \mathbf{3 d}, \mathbf{3 h}-\mathbf{j}$ and $\mathbf{3 l}$ displayed significant inhibitory activity (inhibition zone 22-27 mm, Table III) against Pseudomonas aeruginosa, whereas the other compounds showed moderate activity (inhibition zone 18-22 $\mathrm{mm}$ ) against the same organism. In this regard, compound 3d with $4-\mathrm{Cl}-\mathrm{C}_{6} \mathrm{H}_{4}$ group at the fourth position of the pyrazolopyrimidine ring showed the highest activity (inhibition zone $27 \mathrm{~mm}$ ). When the position of the chloro substituent group was changed either to the second (3b) or third position (3c) in the phenyl ring, a marked decrease in activity against $P$. aeruginosa was observed. It was also observed that substitution with $2-\mathrm{OH}-\mathrm{C}_{6} \mathrm{H}_{4}(3 \mathbf{e})$, $4-\mathrm{OH}-\mathrm{C}_{6} \mathrm{H}_{4}(3 \mathbf{f})$ or $\mathrm{CH}=\mathrm{CH}-\mathrm{C}_{6} \mathrm{H}_{5}$ (3k) groups at the fourth position of the pyrazolopyrimidine ring resulted in a marked decrease in activity against the same microorganism. All the tested compounds exhibited either moderate or weak inhibitory activity against Escherichia coli, Staphylococcus aureus and Bacillus megaterium.

Antifungal screening revealed moderate to weak inhibitory activity against Candida albicans. In this regard, compounds with 3,4-di- $\left(\mathrm{OCH}_{3}\right)_{2}(3 \mathbf{h})$ or $4-\mathrm{N}\left(\mathrm{CH}_{3}\right)_{2}(3 \mathbf{j})$ bulky groups in the phenyl ring present at the fourth position of the pyrazolopyrimidine ring exhibited maximum activity (inhibition zone $26 \mathrm{~mm}$ in both cases). In the present investigation, activities of the tested compounds were much weaker than that of the standard drug. 
Compounds $3 \mathbf{h}-\mathbf{j}$ showed significant inhibition against the acetic acid induced writhing (55.2-59.6\%), compared to the reference drug diclofenac sodium (62.6\% inhi-

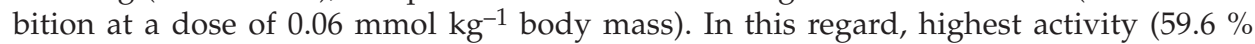
inhibition) was observed for compound $3 \mathbf{j}$. It was also observed that compounds with $\mathrm{C}_{6} \mathrm{H}_{5}$ (3a), 4-Cl- $\mathrm{C}_{6} \mathrm{H}_{4}$ (3d) or 2-furyl (3l) groups at the fourth position of the pyrazolopyrimidine ring resulted in a marked decrease in analgesic activity (36.6-41.7\% inhibition). It is evident that substitution of $3-\mathrm{NO}_{2}-\mathrm{C}_{6} \mathrm{H}_{4}, 4-\mathrm{N}\left(\mathrm{CH}_{3}\right)_{2}-\mathrm{C}_{6} \mathrm{H}_{3}$ or $3,4-\left(\mathrm{OCH}_{3}\right)_{2}-\mathrm{C}_{6} \mathrm{H}_{3}$ (in $3 \mathbf{i}$, $3 \mathbf{j}$ and $\mathbf{3 h}$ ) bulky groups in the phenyl ring present at the fourth position of the pyrazolopyrimidine ring is optimal for inhibition against the acetic acid induced writhing. However, all the tested compounds were found to be significantly less potent compared to the standard drug.

Analgesic activity of the synthesized compounds was also evaluated by Eddy's hot plate method (17). Screening results at the $0.30 \mathrm{mmol} \mathrm{kg}^{-1}$ (body mass) dosage are summarized in Table V. Derivatives $\mathbf{3 h}, \mathbf{3 i}$ and $3 \mathbf{l}$ exhibited fast analgesic activity (49.8-58.4 $\%$ analgesia), as evident from the observation at $30 \mathrm{~min}$ following oral administration $(0.30 \mathrm{mmol} \mathrm{kg}-1)$. After $1 \mathrm{~h}$, compound $3 \mathrm{~h}$ with 3,4- $\left(\mathrm{OCH}_{3}\right)_{2}-\mathrm{C}_{6} \mathrm{H}_{3}$ group at the fourth position of the pyrazolopyrimidine ring showed maximum activity (73.2 \% analgesia) compared to the reference drug paracetamol (70\% analgesia at $\left.0.66 \mathrm{mmol} \mathrm{kg}{ }^{-1}\right)$, while after 2 and $3 \mathrm{~h}$ compounds $3 \mathrm{~h}$ and 31 showed marked activity (61.4-75.0\% analgesia) against thermal stimuli compared to the reference drug (86.9 and $58.7 \%$ analgesia, respectively). It is evident from the results that the presence of either $\mathrm{C}_{6} \mathrm{H}_{4}$ or $3-\mathrm{NO}_{2}-\mathrm{C}_{6} \mathrm{H}_{4}$ group markedly decreased the analgesic activity. It is also important to note that, except for compounds $3 \mathrm{~h}$ and 31, a marked decrease in analgesic activity was observed after $3 \mathrm{~h}$ following oral administration of test compounds. The promising analgesic activity shown by compounds $\mathbf{3 h}$ and $\mathbf{3} \mathbf{j}$ in both models indicated that these compounds might possess centrally and peripherally mediated analgesic properties.

At first, the anti-inflammatory activity of the synthesized compounds was studied (18)

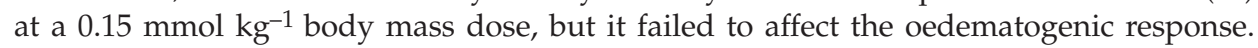
The anti-inflammatory activity results determined at the $0.30 \mathrm{mmol} \mathrm{kg}^{-1} \mathrm{~b} . \mathrm{m}$. dosage are summarized in Table VI. Compounds $\mathbf{3} \mathbf{f}$ and $\mathbf{3} \mathbf{j}$ showed a rapid onset of action (44.6 and $56.8 \%$ inhibition, respectively), as evident from the observation $30 \mathrm{~min}$ after carrageenean injection. After $1 \mathrm{~h}$, maximum activity (67.7\% protection) was observed in compound $\mathbf{3 j}$ having 4- $\mathrm{N}\left(\mathrm{CH}_{3}\right)_{2}-\mathrm{C}_{6} \mathrm{H}_{4}$ group at the fourth position of the pyrazolopyrimidine ring and after $2 \mathrm{~h}$ compound $3 \mathbf{j}$ exhibited potent activity (74.7 \% protection) when compared to the reference drug diclofenac sodium $\left(61.1 \%\right.$ at $0.06 \mathrm{mmol} \mathrm{kg}^{-1} \mathrm{~b} . \mathrm{m}$.). In general, a sharp decline in anti-inflammatory activity was observed $3 \mathrm{~h}$ after carrageenean injection. The other compounds showed moderate to weak activity (12.5-35.9\% inhibition) at all time points and were less potent compared to the standard drugs.

Carrageenean-induced oedema is a biphasic response. The first phase is mediated through the release of histamine, serotonin and kinins, whereas the second phase is related to the release of prostaglandin and slow reacting substances with peaks at $3 \mathrm{~h} \mathrm{(21,}$ 22). In the present study, previous oral treatment with the test compounds was effective in reducing the carrageenean induced paw oedema in rats between $30 \mathrm{~min}$ and the second hour after the injection. This suggests that the compounds probably inhibited the release of histamine, serotonin and kinins in the first phase. 
Compounds $3 \mathrm{~h}-\mathrm{j}$ were evaluated for their ulcerogenic potential in rats according to the method reported by Cioli et al. (19). The results indicated low ulcerogenic potential of the tested compounds (severity index 2.5-3.7). The lowest reduction in ulcerogenic potential (severity index 3.0) was observed for compound $3 \mathbf{j}$ (Table VII). The other tested compounds, $\mathbf{3 h}$ and $\mathbf{3 i}$, also exhibited a better gastrointestinal safety profile (severity index 3.7 and 3.5, respectively) compared to the standard drug diclofenac sodium (severity index 6.1).

No behavioral changes in animals were observed during the experiment and at the end hematological parameters were estimated and there were no observable changes. In the present study mortality was not observed and the tested compounds were well tolerated by the experimental animals up to $1000 \mathrm{mg} \mathrm{kg}^{-1}$.

\section{CONCLUSIONS}

In summary, various benzothiazole derivatives were prepared with the objective of developing dual antimicrobial-anti-inflammatory agents with minimum ulcerogenic effects. Among these compounds, 4-[1-(1,3-benzothiazol-2-yl)-3-methyl-1H-pyrazolo[3,4d]pyrimidin-4-yl]- $N, N$-dimethylaniline $(3 \mathbf{j})$ showed the most prominent and consistent activity and the lowest ulcerogenicity. Therefore, compound $3 \mathbf{j}$ could represent a fruitful matrix for the development of a new class of dual antimicrobial-anti-inflammatory agents.

\section{REFERENCES}

1. G. Dannhardt and W. Kiefer, Cyclooxygenase inhibitors-current status and future prospects, Eur. J. Med. Chem. 36 (2001) 109-126; DOI: 10.1016/S0223-5234(01)01197-7.

2. Y. Song, D. T. Connor, A. D. Sercel, R. J. Sorenson, R. Doubleday, P. C. Unangst, B. D. Roth, V. G. Beylin, R. B. Gilbertsen, K. Chan, D. J. Schrier, A. Guglietta, D. A. Bornemeier and R. D. Dyer, Synthesis, structure-activity relationships, and in vivo evaluations of substituted di-tert-butylphenols as a novel class of potent, selective, and orally active cyclooxygenase- 2 inhibitors. 2 . 1,3,4- and 1,2,4-thiadiazole series, J. Med. Chem. 42 (1999) 1161-1169; DOI: 10.1021/jm980570y.

3. S. M. Sondhi, N. Singhal, M. Johar, B. S. Reddy and J. W. Lown, Heterocyclic compounds as inflammation inhibitors, Curr. Med. Chem. 9 (2002) 1045-1074; DOI: 10.2174/0929867023370248.

4. R. J. Flower, The development of COX2 inhibitors, Nat. Rev. Drug Discov. 2 (2003) 179-191; DOI: $10.1038 /$ nrd1034.

5. O. Moukha-Chafiq, M. L. Taha, H. B. Lazrek, J. J. Vasseur, C. Pannecouque, M. Witvrouw and E. D. Clercq, Synthesis and biological activity of some 4-substituted 1-[1-(2,3-dihydroxy-1-propoxy)methyl-1,2,3-triazol-(4 \& 5)-ylmethyl]-1H-pyrazolo[3,4-d]pyrimidines, Farmaco 57 (2002) 27-32; DOI: 10.1016/S0014-827X(01)01152-1.

6. S. M. Gomha and H. M. Hassaneen, Synthesis and antimicrobial activity of some new pyrazoles, fused pyrazolo[3,4-d]-pyrimidine and 1,2-dihydroimidazo-[2,1-c][1,2,4]triazin-6-one derivatives, Molecules 16 (2011) 6549-6560; DOI: 10.3390/molecules16086549.

7. J. M. Quintela, C. Peinado, L. Gonzalez, I. Devesa, M. L. Ferrandiz, M. J. Alcaraz and R. Riguera, 6-Dimethylamino $1 H$-pyrazolo[3,4- $d$ ]pyrimidine derivatives as new inhibitors of inflammatory mediators in intact cells, Bioorg. Med. Chem. 11 (2003) 863-868; DOI: 10.1016/S0968-0896(02)00562-X. 
8. A. Latrofa, M. Franco, A. Lopedota, A. Rosato, D. Carone and C. Vitali, Structural modifications and antimicrobial activity of $N$-cycloalkenyl-2-acylalkylidene-2,3-dihydro 1,3 benzothiazoles, Farmaco 60 (2005) 291-297; DOI: 10.1016/j.farmac.2005.01.010.

9. S. Bondock, W. Fadaly and M. A. Metwally, Enaminonitrile in heterocyclic synthesis: Synthesis and antimicrobial evaluation of some new pyrazole, isoxazole and pyrimidine derivatives incorporating a benzothiazole moiety, Eur. J. Med. Chem. 44 (2009) 4813-4818; DOI: 10.1016/j.ejmech.2009.07.02.

10. A. Geronikaki, D. H. Litina and M. Amourgianou, Novel thiazolyl, thiazolinyl and benzothiazolyl Schiff bases as possible lipoxygenase's inhibitors and anti-inflammatory agents, Farmaco 58 (2003) 489-495; DOI: 10.1016/S0014-827X(03)00065-X.

11. M. Santagati, M. Modica, A. Santagati, F. Russo, A. Caruso, V. Cutuli, E. Di Pietro and M. AmicoRoxas, Synthesis and pharmacological properties of benzothiazole, 1,3-4-oxadiazole and 1,3,4-thiadiazole derivatives, Pharmazie 49 (1994) 880-884; DOI: 10.1002/chin.199518135.

12. A. Gvozdjakova and H. Ivanovicova, Synthesis and properties of 2-hydrazinobenzothiazole derivatives, Chem. Pap. 40 (1986) 797-800.

13. A. E. G. Hammam and N. M. Youssif, Synthesis and reactions of 2-mercaptobenzothiazole derivatives of expected biological activity, J. Chem. Eng. Data 27 (1982) 207-208; DOI: 10.1021/je00028a032.

14. L. Boyanova, G. Gergova, R. Nikolov, S. Derejian, E. Lazarova, N. Katsarov, I. Mitov and Z. Krastev, Activity of Bulgarian propolis against 94 Helicobacter pylori strains in vitro by agar-well diffusion, agar dilution and disc diffusion methods, J. Med. Microbiol. 54 (2005) 481-483; DOI: 10.1099/ jmm.0.45880-0.

15. Organization for Economic Cooperation and Development, OECD guidelines for Testing of Chemicals. Guideline 423: Acute Oral Toxicity - Acute Toxic Class Method, Adopted; http:/ /www.iccvam. niehs.nih.gov/SuppDocs/FedDocs/OECD/OECD_GL423.pdf, last access: September 28, 2012.

16. H. Y. Young, Y. L. Luo, H. Y. Cheng, W. C. Hsieh, J. C. Liao and W. H. Peng, Analgesic and anti-inflammatory activities of [6]-gingerol, J. Ethnopharmacol. 96 (2005) 207-210; DOI: 10.1016/ j.jep.2004.09.009.

17. S. Su, T. Wang, J. A. Duan, W. Zhou, Y. Q. Hua, Y. P. Tang, L. Yu and D. W. Qian, Anti-inflammatory and analgesic activity of different extracts of Commiphora myrrha, J. Ethnopharmacol. 134 (2011) 251-258; DOI: 10.1016/j.jep.2010.12.003.

18. C. Cicala, S. Morello, A. Alfieri, V. Vellecco, S. Marzocco and G. Autore, Haemostatic imbalance following carrageenan-induced rat paw oedema, Eur. J. Pharmacol. 577 (2007) 156-161; DOI: 10.1016/ j.ejphar.2007.08.007.

19. V. Cioli, S. Putzolu, V. Rossi, P. S. Barcellona and C. Corradino, The role of direct tissue contact in the production of gastro-intestinal ulcers by anti-inflammatory drugs in rats, Toxicol. Appl. Pharmacol. 50 (1979) 283-289; DOI: 10.1016/0041-008X(79)90153-4.

20. M. Amir, S. A. Javed and H. Kumar, Synthesis and biological evaluation of some 4-(1H-indol-3-yl)-6-phenyl-1,2,3,4-tetrahydropyrimidin-2-ones/thiones as potent anti-inflammatory agents, Acta Pharm. 58 (2008) 467-477; 10.2478/v10007-008-0028-x.

21. A. E. Rashad, M. I. Hegab, R. E. Abdel-Megeida, N. Fathallab and F. M. E. Abdel-Megeid, Synthesis and anti-HSV-1 evaluation of some pyrazoles and fused pyrazolopyrimidines, Eur. J. Med. Chem. 44 (2009) 3285-3292; DOI: 10.1016/j.ejmech.2009.02.012.

22. P. M. Brooks and R. O. Day, Nonsteroidal antiinflammatory drugs-differences and similarities, N. Engl. J. Med. 324 (1991) 1716-1725; DOI: 10.1056/NEJM199106133242407.

23. V. Araujo-Neto, R. R. Bomfim, V. O. B. Oliveira, A. M. P. R. Passos, J. P. R. Oliveira, C. A. Lima, S. S. Mendes, C. S. Estevam and S. M. Thomazzi, Therapeutic benefits of Sideroxylon obtusifolium (Humb. ex Roem. \& Schult.) T. D. Penn., Sapotaceae, in experimental models of pain and inflammation, Braz. J. Pharmacogn. 20 (2010) 933-938; DOI: 10.1590/S0102-695X2010005000043. 